\title{
Aktivitas Antioksidan Ekstrak Rumput Laut Padina sp. Dari Perairan Bandengan Jepara Dengan Metode Transfer Elektron
}

\author{
Jelita Rahma Hidayati*, Ali Ridlo, Rini Pramesti \\ Departemen Ilmu Kelautan, Fakultas Perikanan dan Ilmu Kelautan, Universitas Diponegoro \\ Kampus Tembalang, Semarang 50275 Telp/Fax. 024-7474698 \\ Email: jelitarahmahidayati@gmail.com
}

\begin{abstract}
Abstrak
Antioksidan merupakan senyawa yang dapat menghambat atau mencegah reaksi oksidasi. Antioksidan sintetik kurang aman bagi kesehatan karena bersifat karsinogen, sehingga diperlukan sumber antioksidan alami seperti Padina sp. yang mengandung senyawa bioaktif seperti fenolat, klorofil a, karotenoid dan $\beta$-karoten. Padina sp. diambil dari Perairan Bandengan Jepara dan dikeringkan dengan Solar Tunnel Dryer (STD) selama 3 hari. Sampel dimaserasi secara bertingkat dengan pelarut n-heksana, etil asetat dan metanol lalu diuapkan dengan rotary evaporator. Aktivitas antioksidan ditentukan dengan metode DPPH (1,1-diphenyl-2-picrylhidrazyl) sebagai radikal bebas. Nilai $\mathrm{IC}_{50}$ digunakan untuk mengetahui aktivitas antioksidan pada sampel yang diinkubasi selama 30 menit dan diukur nilai absorbansinya pada panjang gelombang $514 \mathrm{~nm}$. Kandungan total fenolat diuji menggunakan larutan Folin-Ciocalteu dengan asam galat sebagai standar yang diukur pada panjang gelombang $725 \mathrm{~nm}$. Kandungan klorofil a diukur pada panjang gelombang $663 \mathrm{~nm}$ dan $645 \mathrm{~nm}$ sedangkan karotenoid diukur pada panjang gelombang $480 \mathrm{~nm}$. Hasil penelitian menunjukkan nilai $\mathrm{IC}_{50}$ terbaik dicapai ekstrak etil asetat yaitu 137,02 ppm, diikuti ekstrak nheksana 1234,41 ppm dan ekstrak metanol 1554,45 ppm. Kandungan total fenolat tertinggi dicapai pada ekstrak etil asetat yaitu 12,09 mg GAE/g sampel, diikuti ekstrak n-heksana 9,32 mg GAE/g sampel dan ekstrak metanol 0,22 mg GAE/g sampel. Kandungan klorofil a tertinggi dicapai ekstrak etil asetat yaitu 2,67 $\mathrm{mg} / \mathrm{g}$ sampel, diikuti ekstrak metanol 0,39 mg/g sampel dan ekstrak n-heksana 0,30 mg/g sampel. sampel). Kandungan karotenoid tertinggi dicapai ekstrak etil asetat yaitu 5,37 $\mu \mathrm{mol} / \mathrm{g}$ sampel, diikuti ekstrak nheksana $1,85 \mu \mathrm{mol} / \mathrm{g}$ sampel dan ekstrak metanol $0,53 \mu \mathrm{mol} / \mathrm{g}$ sampel. Ekstrak etil asetat memiliki aktivitas antioksidan kategori sedang dan ekstrak metanol serta n-heksana memiliki aktivitas antioksidan kategori sangat lemah.
\end{abstract}

Kata kunci: Padina sp., Antioksidan, DPPH

\section{Abstract}

Antioxidant are the compounds capable to inhibit and prevent oxidation reaction. Synthetic antioxidant less safe for health because it is a carsinogen, so required source of natural antioxidant as Padina sp. that contains bioactive compounds as fenolat, chlorophyll a, carotenoid and $\beta$-caroten. Padina sp was taken from Bandengan water Jepara and dried with Solar Tunnel Dryer (STD) during 3 days. Macerated sample were stratified with n-heksana, ethyl acetate and methanol then evaporated with a rotary evaporator. The antioxidant activity was determined using a DPPH solution (1,1-diphenyl-2-picrylhidrazyl) as free radicals. IC 50 value used to determine the antioxidant activity of sample were incubated for 30 minutes and measured at wavelength $514 \mathrm{~nm}$. Total phenolic content tested by the Folin-Ciocalteu solution with gallic acid as standard and measured at a wavelength of $725 \mathrm{~nm}$, while the chlorophylls a content were measured at a wavelength of $663 \mathrm{~nm}$ and $645 \mathrm{~nm}$ and carotenoids were measured at a wavelength of 480 $\mathrm{nm}$. The results showed best $\mathrm{IC}_{50}$ is achieved by ethyl acetat extract 137,02 ppm, followed by $n$-heksana extract 1234,41 ppm and methanol extract 1554,45 ppm. The highest total phenolic content is achieved by ethyl acetat extract 12,09 mg GAE/g sample, followed by n-heksana extract 9,32 mg GAE/g sample and methanol extract 0,22 mg GAE/g sample. The highest chlorophyll a content is achieved by ethyl acetat extract $2,67 \mathrm{mg} / \mathrm{g}$ sample, followed by methanol extract 0,39 $\mathrm{mg} / \mathrm{g}$ sample and $\mathrm{n}$-heksana extract 0,30 mg/g sample. The highest carotenoids content is achieved by ethyl acetat extract 5,37 $\mu \mathrm{mol} / \mathrm{g}$ sample, followed by n-heksana extract 1,85 $\mathrm{mol} / \mathrm{g}$ sample and methanol extract 0,53 $\mathrm{mmol} / \mathrm{g}$ sample. Eethyl acetate extract categorized as medium antioxidant activity and methanol and n-heksana extracts categorized as very weak antioxidant activity.

Keywords: Padina sp., Antioksidan, DPPH

$\begin{array}{llll}\text { *Corresponding author } & \text { http://ejournal.undip.ac.id/index.php/buloma } & \text { Diterima/Received } & : 31-01-2017 \\ \text { buloma.undip@gmail.com } & & \text { Disetujui/Accepted } & : 27-02-2017\end{array}$




\section{PENDAHULUAN}

Antioksidan merupakan senyawa yang dapat menghambat kerja radikal bebas dengan cara mendonorkan satu atau lebih elektronnya. Radikal bebas adalah atom, molekul atau senyawa yang mempunyai elektron tidak berpasangan sehingga bersifat reaktif dan mudah bereaksi dengan zat lain seperti protein, lemak dan DNA (Winarti, 2010). Radikal bebas seperti anion superoksida $\left({ }^{*} \mathrm{O}_{2}{ }^{-}\right)$, radikal hidroksil $\left(\mathrm{OH}^{*}\right)$, radikal alkoksil $\left(\mathrm{RO}^{*}\right)$, oksida nitrit $\left(\mathrm{NO}^{*}\right)$, Peroksi nitrit $\left(\mathrm{OONO}^{*}\right)$, hidrogen peroksida $\left(\mathrm{H}_{2} \mathrm{O}_{2}\right)$ dan singlet oksigen $\left({ }^{1} \mathrm{O}_{2}\right)$ terbentuk secara terus menerus di dalam tubuh melalui proses metabolisme sel normal (Sayuti dan Yerina, 2015) serta dari luar tubuh sebagai respons adanya radiasi sinar gama, ultraviolet (UV), polusi lingkungan dan asap rokok (Wijaya, 1996). Radikal bebas menyebabkan berbagai penyakit seperti kanker, aterosklerosis, jantung, diabetes, parkinson, alzheimer, artritis dan gangguan sistem kekebalan tubuh (Amic et al., 2003).

Antioksidan terbagi menjadi dua jenis yaitu antioksidan sintetik dan alami. Antioksidan sintetik yang banyak digunakan adalah butil hidroksi anisol (BHA), butil hidroksi toluen (BHT), propil galat (PG), tertbutil hidroksi quinon (TBHQ) dan analog alfa tokoferol (AAT). Antioksidan sintetik bersifat toksik, sehingga senyawa antioksidan alami menjadi penting untuk dikembangkan. Antioksidan alami mengandung berbagai senyawa, seperti fenolat (Fenol dan polifenol), flavonoid, karotenoid, steroid dan senyawa tiol (Lu et al., 2010). Salah satu bahan alami dari laut yang melimpah dan dapat dimanfaatkan sebagai antioksidan adalah Padina sp.

Padina sp. berpotensi sebagai antioksidan alami dan mempunyai kandungan senyawa aktif di dalamnya seperti flavonoid, alkaloid, tanin, triterpenoid, saponin, fenolat dan pigmen seperti klorofil a, klorofil c, karotenoid, fukosantin, fukoxantol dan $\beta$-karoten (Sari, 2016). Padina australis dari Pantai Binuangeun, Banten mempunyai nilai hambatan terhadap radikal bebas DPPH sebesar $53 \%$ pada dosis 50 ppm (Nursid, 2013). Ekstrak metanol P. australis dari Perairan Maluku memiliki nilai $\mathrm{IC}_{50}$ sebesar 200,88 ppm, ekstrak etil asetat sebesar 183,09 dan ekstrak nheksana sebesar 900 ppm (Setha et al., 2013). Padina sp. yang diambil dari Pantai Drini, Gunung Kidul memiliki nilai $\mathrm{IC}_{50} 37,68$ ppm (Husni, 2014).

Penelitian ini bertujuan untuk menentukan aktivitas antioksidan ekstrak n-heksana, etil asetat dan metanol Padina sp. serta menentukan kandungan total fenolat, klorofil a dan karotenoid.

\section{MATERI DAN METODE}

Materi yang digunakan adalah Padina sp. yang diambil dari Perairan Bandengan Jepara dan dikeringkan dengan Solar Tunnel Dryer (STD).

\section{Analisis Kadar Air Padina sp. kering}

Cawan kosong dipanaskan dalam oven dengan suhu $100{ }^{\circ} \mathrm{C}$ selama 15 menit kemudian didinginkan dalam desikator selama 20 menit dan ditimbang. Padina sp. kering sebanyak $15 \mathrm{~g}$ dalam cawan dikeringkan dengan oven pada suhu $100{ }^{\circ} \mathrm{C}$ selama 30 menit atau sampai beratnya konstan kemudian didinginkan dalam desikator dan ditimbang. Kadar air dihitung menggunakan rumus (AOAC, 1984):

Kadar air $(\%)=\frac{(b-c)}{(b-a)} \times 100 \%$

$\mathrm{a}=$ berat cawan kosong

$\mathrm{b}=$ berat cawan + sampel sebelum dikeringkan

$\mathrm{c}=$ berat cawan + sampel setelah dikeringkan

\section{Ekstraksi Sampel}

Ekstraksi Padina sp. dilakukan dengan cara maserasi bertingkat menggunakan n-heksana, etil asetat dan metanol (polar) (Setha et al., 2013). Sampel kering sebanyak 50 gram dipotong kecilkecil $( \pm 5 \mathrm{~mm})$ dan dimaserasi menggunakan $\mathrm{n}$ heksana sebanyak $400 \mathrm{~mL}$ selama 24 jam pada suhu ruang $\pm 27{ }^{0} \mathrm{C}$, kemudian disaring. Residu dimaserasi kembali selama 24 jam dan disaring lalu filtrat diuapkan menggunakan rotary evaporator pada suhu $37^{\circ} \mathrm{C}$. Residu diekstrak kembali berturut-turut dengan etil asetat dan metanol dengan cara yang sama.

\section{Penentuan Absorbansi Maksimum DPPH}

Larutan DPPH 0,1 mM diambil sebanyak 4 $\mathrm{mL}$ kemudian dimasukkan ke dalam kuvet dan diamati absorbansinya menggunakan spektrofotometer pada panjang gelombang 400 $800 \mathrm{~nm}$ (Patria dan Soegihardjo, 2013). Panjang gelombang yang menunjukkan absorbansi maksimum akan digunakan untuk analisis.

\section{Penentuan Waktu Inkubasi}

Sebanyak $3 \mathrm{~mL}$ ekstrak $50 \mathrm{ppm}$ ditambah $1 \mathrm{~mL}$ larutan DPPH 0,1 mM, lalu dimasukkan ke dalam kuvet dan diamati absorbansinya pada panjang gelombang maksimum DPPH $(514 \mathrm{~nm})$ setiap 5 menit selama 40 menit (Patria dan Soegihardjo, 2013). Reaksi dianggap sempurna saat absorbansi menunjukkan nilai yang konstan. 


\section{Uji Kualitatif Antioksidan}

Masing-masing ekstrak diukur absorbansinya pada panjang gelombang 400 - 800 nm. Langkah yang sama dilakukan pada ekstrak yang ditambahkan DPPH 0,1 mM. Hilangnya puncak absorbansi maksimum DPPH menunjukkan adanya peredaman DPPH oleh ekstrak.

\section{Uji Aktivitas Antioksidan}

Uji aktivitas antioksidan menggunakan radikal bebas DPPH dan dilakukan secara spektrofotometri (Setha et al., 2013) dengan modifikasi variasi konsentrasi. Sebanyak $3 \mathrm{~mL}$ larutan uji (50, 100, 150, 200, 250, 300, 350, 400 ppm) ditambahkan $1 \mathrm{~mL}$ DPPH $0,1 \mathrm{mM}$, kemudian diinkubasi selama 30 menit pada suhu ruang $\left(27{ }^{\circ} \mathrm{C}\right)$. Absorbansi diukur pada panjang gelombang $514 \mathrm{~nm}$. Persentase inhibisi dihitung dengan menggunakan rumus (Moubayed et al., 2016) :

Persentase Inhibisi $=\frac{(A-B)}{A} \times 100 \%$

$\mathrm{A}=$ absorbansi larutan DPPH

$\mathrm{B}=$ absorbansi DPPH + Ekstrak

\section{Pengukuran Kandungan Senyawa Total Fenolat}

Asam galat dengan konsentrasi 5, 10,15, 20 dan 25 ppm diambil sebanyak $2 \mathrm{~mL}$, ditambahkan $5 \mathrm{~mL}$ aquadest dan $0,5 \mathrm{~mL}$ reagen FolinCiocalteu. Larutan didiamkan selama 3 menit kemudian ditambahkan $1 \mathrm{~mL}$ larutan $\mathrm{Na}_{2} \mathrm{CO}_{3} 5 \%$ dan diinkubasi pada suhu ruang selama 1 jam dalam kondisi gelap. Absorbansi diukur pada menyatakan hubungan antara konsentrasi asam galat dengan nilai absorbansinya. Langkah yang sama dilakukan pada masing-masing ekstrak.panjang gelombang $725 \mathrm{~nm}$ (Ghafar, 2010), selanjutn dibuat kurva kalibrasi yang Nilai total fenolat dinyatakan dalam mg Galic Acid Equivalent (GAE)/1000 g dan dihitung menggunakan rumus (Ghafar, 2010):

$$
\text { Total Fenol }=\frac{(\mathrm{axV}) / 1000}{\mathrm{G}}
$$

$\mathrm{a} \quad=$ Konsentrasi asam galat dalam sampel uji (mg/L)

$\mathrm{V} \quad=$ Volume total larutan uji $(\mathrm{mL})$

$\mathrm{G} \quad=$ Berat ekstrak yang digunakan $(\mathrm{g})$

$1000=$ Faktor konversi volume total larutan

\section{Pengukuran Kandungan Senyawa Klorofil a} dan Karotenoid

Masing-masing ekstrak dilarutkan dengan aseton p.a hingga konsentrasi 100 ppm dan dimasukkan ke dalam kuvet sebanyak $3 \mathrm{~mL}$. Absorbansinya diukur pada panjang gelombang $645 \mathrm{~nm}, 663 \mathrm{~nm}$ dan $480 \mathrm{~nm}$ (Kurniawan, 2010). Kandungan klorofil a dan karotenoid dihitung berdasarkan rumus berikut (Gross, 1991):

$$
\begin{aligned}
& \text { Klorofil a }=12,7 \times \mathrm{A}_{663}-2,69 \times \mathrm{A}_{645} \\
& \begin{array}{c}
\text { Karotenoid }= \\
\frac{(\mathrm{A} 430+(0,114 \times \mathrm{A} 66 \mathrm{~B})-(0,538 \times \mathrm{A} 645) \times \mathrm{V} \times 100 \mathrm{C}}{112,5 \times \mathrm{U}, 1 \times 1 \mathrm{U}}
\end{array}
\end{aligned}
$$

\section{HASIL DAN PEMBAHASAN}

Padina sp. dikeringkan dengan Solar Tunnel Dryer (STD) untuk menghindari proses pembusukan. Kadar air Padina sp. kering adalah $6 \%$, sehingga baik untuk disimpan dalam jangka panjang (winarno, 1992).

Padina sp. kering diekstraksi secara bertingkat dengan pelarut $n$-heksana, etil asetat dan metanol. Hal ini dilakukan agar senyawa yang terkandung dapat terekstrak sempurna, karena masing - masing pelarut mempunyai kemampuan berbeda dalam melarutkan senyawa bioaktif (Sarastani et al., 2002). Pelarut n-heksana dapat melarutkan senyawa non polar seperti klorofil, lipid dan lilin. Etil asetat dapat melarutkan senyawa semi polar seperti flavonoid, saponin, terpenoid, sterol dan tanin, sedangkan metanol dapat melarutkan senyawa polar seperti alkaloid, flavonoid, saponin dan karbohidrat (Kuppusamy et al., 2015).

Rendemen ekstrak Padina sp. tertinggi dicapai pada ekstrak metanol yaitu 1,78 \%. Hal ini mengindikasikan Padina sp. mengandung senyawa bioaktif yang besifat polar. Secara visual ekstrak metanol berwarna hijau tua, ekstrak etil asetat berwarna cokelat dan ekstrak n-heksana berwarna kuning kecokelatan. Warna hijau diduga adanya kandungan klorofil, sedangkan warna coklat diduga adanya kandungan karotenoid dan pigmen lain. Warna dasar rumput laut cokelat disebabkan karena adanya pigmen karotenoid jenis fukosantin yang Iebih dominan dari klorofil a dan c serta $\beta$-karoten (Kailola et al., 2012). Hasil ekstraksi dapat dilihat pada Tabel 1.

Aktivitas antioksidan ditentukan dengan menggunakan metode transfer elektron dengan DPPH sebagai radikal bebas. Hal ini disebabkan pengukuran dengan DPPH merupakan pengukuran yang sederhana, cepat dan tidak 
membutuhkan banyak reagen (Sayuti dan Yenrina, 2015). Panjang gelombang maksimum DPPH ditentukan untuk mendapatkan nilai absorbansi yang memberikan sensitivitas pengukuran tertinggi. Nilai absorbansi maksimum DPPH dicapai pada panjang gelombang $514 \mathrm{~nm}$.

Hal ini sesuai Miliauskas et al. (2004) yang menyatakan bahwa absorbansi maksimum DPPH terletak antara panjang gelombang $510-520 \mathrm{~nm}$. Perbedaan panjang gelombang terjadi karena adanya perbedaan penggunaan pelarut dan deteksi alat pengukuran.

Pengukuran waktu inkubasi dilakukan untuk menetukan waktu sampel dan DPPH sudah bereaksi sempurna yang ditunjukkan dengan tidak adanya lagi penurunan absorbansi. Sampel yang diinkubasi akan lebih stabil dan memiliki penurunan absorbansi yang lebih signifikan dibandingkan sampel yang tidak diinkubasi (Suroso, 2011).

Nilai absorbansi ekstrak metanol dan etil asetat mengalami penurunan dari menit ke- 5 dan mulai stabil pada menit 30-35, sedangkan ekstrak n-heksana mengalami kenaikan mulai menit ke-5, stabil pada menit ke-30 lalu mengalami penurunan (Gambar 2). Waktu inkubasi yang tepat pada ekstrak metanol, etil asetat dan n-heksana dicapai pada menit ke-30.

Aktivitas antioksidan dapat diketahui dengan uji kualitatif dengan membandingkan spektra ekstrak dan spektra ekstrak yang ditambah DPPH. Spektra masing-masing ekstrak diduga mengandung klorofil dan karotenoid, karena menunjukkan puncak pada panjang gelombang klorofil 400 - $450 \mathrm{~nm}$ dan $650-700 \mathrm{~nm}$ dan panjang gelombang karotenoid $400-500 \mathrm{~nm}$ (Gambar 3) (Limantara, 2008). Spektra campuran ekstrak dan DPPH setelah diinkubasi 30 menit menunjukkan tidak adanya lagi absorbansi maksimum DPPH pada panjang gelombang 514 $\mathrm{nm}$. Hal ini menunjukkan radikal bebas DPPH telah berhasil diredam oleh senyawa antioksidan dalam ekstrak Padina sp dan membentuk senyawa DPPH-H. Peredaman ini menyebabkan terjadinya perubahan warna DPPH dari ungu menjadi kuning muda (Lailiyah,2014).

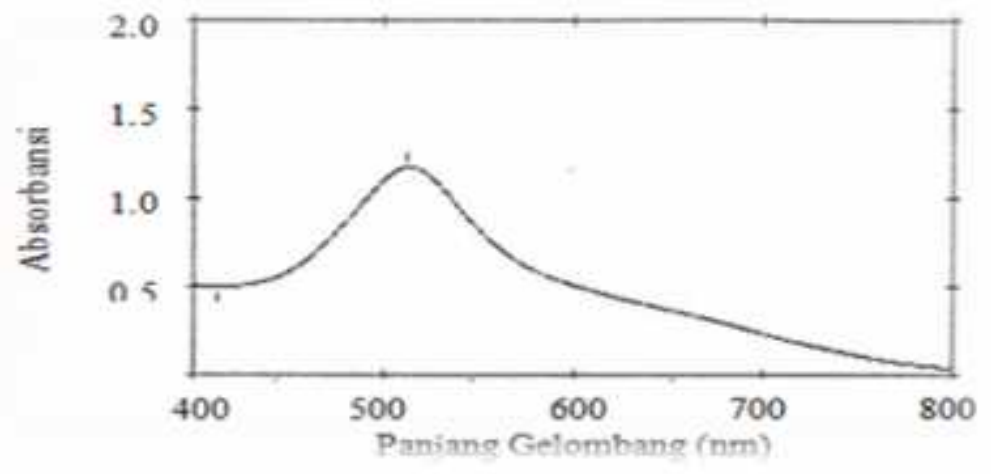

Gambar 1. Spektrum DPPH dalam Metanol

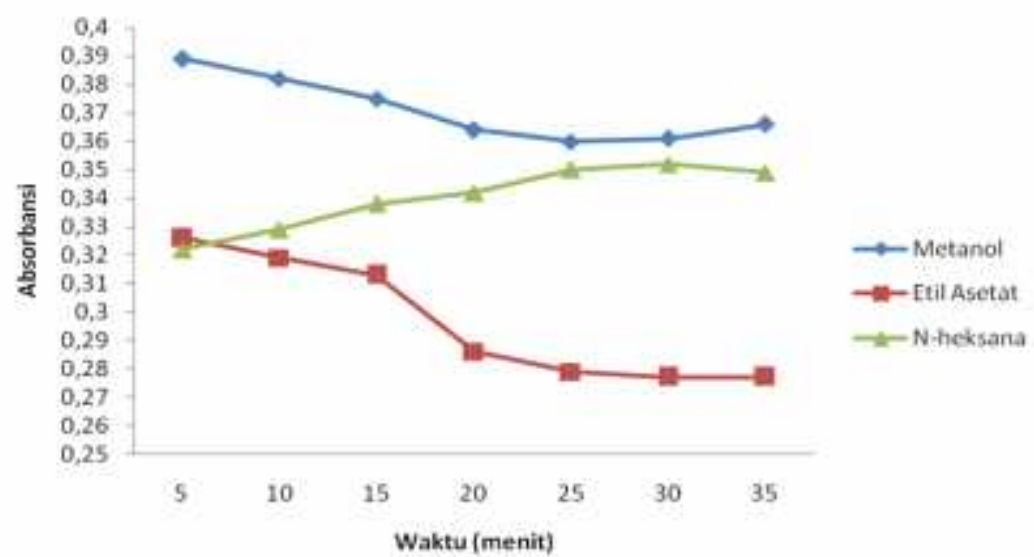

Gambar 2. Grafik nilai absorbansi ekstrak + DPPH per satuan waktu $(\lambda=514 \mathrm{~nm})$ 
Tabel 1. Hasil Ekstraksi Padina sp.

\begin{tabular}{lll}
\hline Pelarut & Rendemen (\%) & Warna \\
\hline Metanol & 1,78 & Hijau Tua \\
Etil Asetat & 0,64 & Cokelat \\
n-Heksana & 0,5 & Kuning Kecokelatan \\
\hline
\end{tabular}

Tabel 3. Kandungan Total Fenolat dan pigmen dalam Ekstrak Padina sp.

\begin{tabular}{llccc}
\hline \multirow{2}{*}{ Parameter yang diukur } & \multicolumn{2}{c}{ Satuan } & \multicolumn{3}{c}{ Ekstrak } \\
\cline { 3 - 5 } & $\mathrm{mg} \mathrm{GAE} / \mathrm{g}$ & n-heksana & Etil Asetat & Metanol \\
\hline Total Fenolat & $\mathrm{mg} / \mathrm{g}$ & 0,32 & 12,09 & 0,22 \\
Klorofil a & $\mu \mathrm{mol} / \mathrm{g}$ & 5,37 & 2,67 & 0,39 \\
Karotenoid & & & 1,85 & 0,53 \\
\hline
\end{tabular}
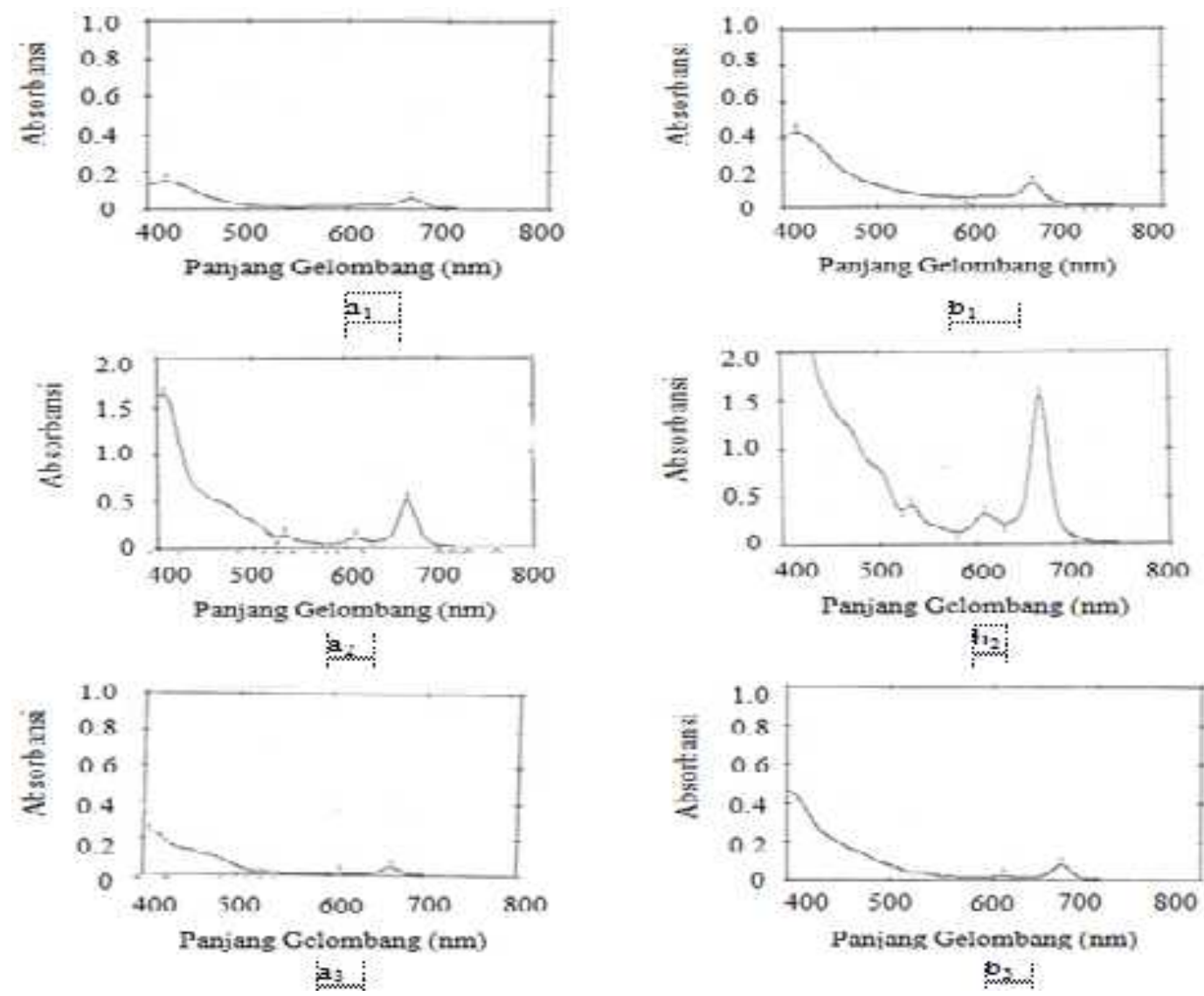

Gambar 3. Spektrum:( $\left.a_{1}\right)$ ekstrak metanol, $\left(a_{2}\right)$ ekstrak etil asetat, $\left(a_{3}\right)$ eksrak n-heksana, $\left(b_{1}\right)$ ekstrak metanol + DPPH, $\left(b_{2}\right)$ ekstrak etil asetat + DPPH, $\left(b_{3}\right)$ ekstrak n-heksana + DPPH

Kemampuan antioksidan ditentukan dengan cara menghitung selisih penurunan nilai absorbansi DPPH terhadap absorbansi campuran ekstrak dan DPPH. Hasilnya menunjukkan semakin tinggi konsentrasi ekstrak, maka tingkat inhibisinya akan bertambah (Gambar 4.) karena semakin banyaknya senyawa antioksidan yang menghambat radikal bebas (Rohimat, 2014).

Hasil penelitian menunjukkan ekstrak etil asetat memiliki nilai $\mathrm{IC}_{50} \quad 137,02 \mathrm{ppm}$ dan tergolong antioksidan kategori sedang/menengah, sedangkan ekstrak n-heksana dan metanol masing-masing memiliki nilai $\mathrm{IC}_{50} 1234,41 \mathrm{ppm}$ dan 1554,45 ppm (Tabel 2.) dan tergolong antioksidan kategori sangat lemah (Molyneux, 2004).

Ekstrak etil asetat memiliki aktivitas yang lebih baik dalam meredam radikal bebas DPPH dibandingkan ekstrak metanol dan-heksana. Hal ini disebabkan kandungan total fenolat, klorofil a 


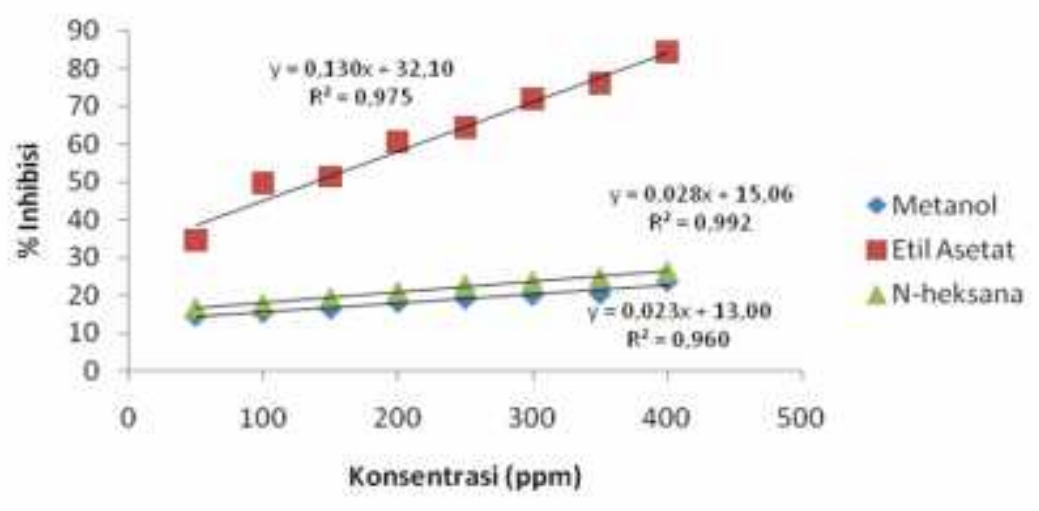

Gambar 4. Aktivitas antioksidan Padina sp.

dan karotenoidnya memiliki nilai yang tinggi dibandingkan ekstrak n-heksana serta ekstrak metanol yaitu $12,09 \mathrm{mg} \mathrm{GAE} / \mathrm{g}, 2,67 \mathrm{mg} / \mathrm{g}$ dan $5,37 \mu \mathrm{mol} / \mathrm{g}$ (Tabel 3). Tingginya kandungan senyawa ini pada ekstrak etil asetat diduga adanya golongan polifenol yang larut seperti tanin, klorofil, karotenoid dan flavanol (Lailiyah, 2014).

Senyawa fenolat bekerja sebagai antioksidan melalui pemutusan rantai reaksi radikal dan mendonorkan atom hidrogennya sehingga dihasilkan radikal bebas yang lebih stabil (Nimse dan Pal, 2015). Aktivitasantioksidan dari flavonoid tergantung pada struktur molekul, pola substitusi gugus hidroksil, ketersediaan hidrogen fenolik dan kemungkinan stabilisasi radikal penoksil yang dihasilkan melalui ikatan hidrogen (Amic et al., 2003). Klorofil bekerja dengan menangkap radikal bebas (Sayuti dan Yenrina, 2015), sedangkan karotenoid bekerja dengan meredam singlet oksigen (Nimse dan Pal, 2015). Bioaktivitas karotenoid dipengaruhi oleh jumlah ikatan rangkap, rantai terbuka dan jumlah substituen oksigennya (Sayuti dan Yenrina, 2015). Senyawa antioksidan dapat langsung bereaksi dengan radikal bebas dan mengubahnya menjadi radikal bebas baru yang kurang aktif dan kurang berbahaya (Amic et al., 2003).

Kemampuan antioksidan yang didapatkan masih lebih rendah dibandingkan P. australis pada kondisi segar yang memiliki nilai $\mathrm{IC}_{50} 37,68$ ppm dan tergolong antioksidan kuat (Husni, 2014). Hal ini diduga pada penelitian ini sampel dikeringkan dengan STD. Kondisi rumput laut (segar atau kering) dapat mempengaruhi senyawa aktif karena kebanyakan komponen aktif tidak tahan terhadap suhu tinggi selama pengeringan (Santoso, 2010). Ditambahkan Budhiyanti et al. (2012), metode ekstraksi, musim, lokasi dan spesies yang digunakan dalam penelitian akan mepengaruhi aktivitas antioksidan dari suatu ekstrak.

\section{KESIMPULAN}

Aktivitas antioksidan ekstrak Padina sp. terbaik dicapai pada ekstrak etil asetat dengan nilai $\mathrm{IC}_{50} 137,02 \mathrm{ppm}$ dan tergolong antioksidan kategori sedang/menengah. Ekstrak n-heksana dan metanol tergolong antioksidan kategori sangat lemah dengan nilai $\mathrm{IC}_{50} 1234,41 \mathrm{ppm}$ dan 1554,45 ppm.

\section{DAFTARPUSTAKA}

Amic A., D.Davidovic-amic, D. Beslo dan N. Trinajstic. 2003. Structure-Radical Scavenging Activity Relationships of Flavonoids. Journal of Croatica Chemica Acta., 76(1):55-61.

AOAC. 1995. Official Methods of Analysis of the Association of Official Analitycal Chemist. Inc. Washington DC. P. $185-189$

Budhiyanti, S.A., S. Raharjo, D.W. Marseno dan I.Y.B. lelana. 2012. Antioxidant Activity of Brown Algae Sargassum Species Extract from the Coastline of Java Island. American J Agricul. Biol. Sci. 7(3): 337-346.

Ghafar, M.F.A., K.N. Prasad., K.K. Weng dan A. Ismail. 2010. Flavonoid, Hesperidine, Total Phenolic Contents and Antioxidant Activities from Citrus Species. African J. Biotechnol. 9(3): 326-330

Gross, J. 1991. Pigments In Vegetables. Chlorophylls and Carotenoids. An avi Book. Van Nostrand Reinhold, New York.

Husni, A., D.R. Putra dan I.Y.B. Lelana. 2014. Aktivitas Antioksidan Padina Sp. pada Berbagai Suhu dan Lama Pengeringan. Jurnal Perikanan. 9(2): 165-173 
Kailola, I.N., A.B. Susanto, B. Prasetyo, Indriatmoko, L. Limantara dan T.H.P. Brotosudarmo. 2012. Pengaruh Beberapa Metode Pengeringan pada Komposisi Pigmen dan Kandungan Trans- Fukosantin Rumput Iaut Cokelat Padina australis. Prosiding Seminar Karotenoid, Antioksidan dan Flavor Tanggal 11-12 Mei 2012, Universitas Kristen Satya Wacana, Salatiga

Kuppusamy P., M.M. Yusoff, N.R. Parine dan N. Govindan. 2015. Evaluation of In-vitro Antioxidant and Antibacterial Properties of Commelina nudiflora L. Extracts Prepared by Different Polar Solvents. Saudi J. Biol. Sci. 22: 293-301.

Lailiyah, A., T.K. Adi, A. Hakim dan E. Yusnawan. 2014. Kapasitas Antioksidan dan Kandungan Total Senyawa Fenolik Ekstrak Kasar Alga Coklat Sargassum cristaefolium dari Pantai Sumenep Madura. J. Alchemy. 3(1): 18-30.

Limantara, L., R. Christiana dan H. Kristopo. 2008. Fotodegradasi dan Aktivitas Antioksidan Klorofil a dari Serbuk Spirulina (Spirulina sp.). Jurnal Chemistry. 8(2):236241.

Lu, J., P.H. Lin, Q. Yao dan C. Chen. 2010. Chemical and Molecular Mechanisms of Antioxidants: Experimental Approaches and Model Systems. J. Molecular Medicine. 14(4): 840-860.

Miliauskas, G., P. Venskutonis, Dan T.A. Van Beck. 2004. Screening of Radical Scavenging Activity of some Medicinal and Aromatic Plant Extracts. J. Food Chem. 85(2):231-237.

Molyneux, P. 2004. The Use of The Stable Free Radical Diphenylpicrylhydrazyl (DPPH) for Estimating Antioxidant Activity. J. Sci. Technol. 26(2): 212-219.

Moubayed, N.M.S., H.J. Al Houri, M.M. Al Khulaifi dan D.A. Al Farraj. 2016. Antimicrobial, Antioxidant Properties and Chemical Composition of Seaweed Collected from Saudi Arabia (Red Sea and arabian Gulf). Saudi J. Biol. Sci.1-8page

Nimse, S.B. dan D. Pal. 2015. Free radicals, natural antioxidants, and their reaction mechanisms. J. Royal Soc. Chem. 5:2798628006.

Nursid, M., T. Wikanta dan R. Susilowati. 2013. Aktivitas Antioksidan, Sitotoksisitas dan Kandungan Fukosantin Ekstrak Rumput Laut Coklat dari Pantai Binuangeun, Banten. J. Ilmu Kelautan. 8(1):73-84.
Patria, W.D. dan C.J. Soegihardjo. 2013. UJI Aktivitas Antioksidan menggunakan Radikal 1,1-Difenil-2-Pikrilhidrazil (DPPH) dan Penetapan Kandungan Fenolik Total Fraksi Etil Asetat Ekstrak Etanolik Daun Benalu (Dendrophthoe Pentandral.Miq.) yang Tumbuh di Pohon Kepel (Stelechocarpus Burahol (B1.) Hook. F.). J. Farmasi Sains., 10(1): 51-60.

Rohimat, I. Widowati, A. Trianto. 2014. Aktivitas Antioksidan Ekstrak Metanol Rumput Laut Coklat (Turbinaria conoides dan Sargassum cristaefolium) yang Dikoleksi dari Pantai Rancabuaya Garut Jawa Barat. J. Mar. Res. 3(3): 304-313.

Rondonuwu, F.S., D.B. Murti, A. Susanto dan O.K. Radjasa. 2016. Pigments Characterization and Molecular Identification of Bacterial Symbionts of Brown Algae Padina sp. Collected from Karimunjawa Island. J. Ilmu Kelautan. 21(2): 59-64.

Santoso, J., Maulida dan S. Suseno. 2010. Aktivitas Antioksidan Ekstrak Metanol, Etil Asetat dan n-heksana Rumput Laut Hijau Caulerpa lentillifera. J. Ilmu Kelautan., Vol. Edisi Khusus: 1-10.

Sarastani, D., S.T. Soekarto, T.R. Muchtadi, D. Fardiaz dan A. Apriyantono. 2002. Aktivitas Antioksidan Ekstrak dan Fraksi Ekstrak Biji Antung (Parinarium glaberrimum). J. Teknologi dan Industri Pangan. 13(2):149156.

Sari, D.P., D.H.C. Pangemanan dan Juliatri. 2016. Uji Daya Hambat Ekstrak Alga Coklat (Padina australis Hauck) terhadap Pertumbuhan Bakteri Porphyromonas Gingivalis Secara In Vitro. Jurnal e-GiGi., 4(2): 140-144.

Sayuti, K. dan R. Yenrina. 2015. Antioksidan Alami dan Sintetik. Andalas University Press, Padang.

Tamat, S. R., T. Wikanta dan L. S. Maulina. 2007. Aktivitas Antioksidan dan Toksisitas Senyawa Bioaktif dari Ekstrak Rumput Laut Hijau Ulva reticulate Forsskal. J. Ilmu Kefarmasian Indonesia. 5(1): 31-36.

Wijaya A. 1996. Radikal Bebas dan Parameter Status Antioksidan. Forum Diagnosticum. Laboratorium Klinik Prodia., 1:1-12.

Winarno F.G. 1984. Kimia Pangan dan Gizi. Gramedia, Jakarta.

Winarti, S. 2010. Makanan Fungsional. Kaisius, Yogyakarta. 